\title{
The changing role of history in restoration ecology
}

\author{
Eric Higgs ${ }^{1 *}$, Donald A Falk ${ }^{2}$, Anita Guerrini ${ }^{3}$, Marcus Hall ${ }^{4}$, Jim Harris ${ }^{5}$, Richard J Hobbs ${ }^{6}$, \\ Stephen T Jackson ${ }^{7 \dagger}$, Jeanine M Rhemtulla ${ }^{8}$, and William Throop ${ }^{9}$
}

In the face of rapid environmental and cultural change, orthodox concepts in restoration ecology such as historical fidelity are being challenged. Here we re-examine the diverse roles played by historical knowledge in restoration, and argue that these roles remain vitally important. As such, historical knowledge will be critical in shaping restoration ecology in the future. Perhaps the most crucial role in shifting from the present version of restoration ecology ("v1.0") to a newer formulation ("v2.0") is the value of historical knowledge in guiding scientific interpretation, recognizing key ecological legacies, and influencing the choices available to practitioners of ecosystem intervention under conditions of open-ended and rapid change.

Front Ecol Environ 2014; 12(9): 499-506, doi:10.1890/110267

$F$ or several decades, the science of restoration ecology and the practice of ecological restoration have thrived on the notion that historical knowledge is a keystone concept (Swetnam et al. 1999; Egan and Howell 2001; Higgs 2003; Hall 2010). The approach has shifted gradually over time, from a former reliance on fixed reference points and composition to a more recent focus on "process-oriented configurations" such as natural range of variation and multiple potential trajectories (Landres et al. 1999; Falk et al. 2006; Choi 2007).

Restoration ecology is poised for more important change. The intensification and acceleration of anthropogenic modifications to ecosystems, coupled with shifting cultural views of nature, are challenging the role of historical knowledge. As climatic and other environmental variables shift outside of their previous ranges (within the time frame

\section{In a nutshell:}

- Under conditions of rapid environmental and cultural change, some have questioned the relevance of historical knowledge, challenging its traditional role as a guide in restoration ecology

- Traditional restoration ecology (termed Restoration "v1.0" in this article) has been driven by specific historically based goals; a newer version (Restoration "v2.0") uses historical knowledge as a guide and not as a template, accepts multiple potential trajectories for ecosystems, emphasizes process over structure, and embraces pragmatic goals for human well-being (eg poverty alleviation)

- We identify nine types of historical knowledge with meaningful current and future value in restoration and intervention ecology

${ }^{1}$ School of Environmental Studies, University of Victoria, Victoria, Canada ${ }^{*}$ ehiggs@uvic.ca); ${ }^{2}$ School of Natural Resources and the Environment, University of Arizona, Tucson, AZ; ${ }^{3}$ School of History, Philosophy, and Religion, Oregon State University, Corvallis, OR; continued on p 506

defined broadly as the early Holocene to the present; ie the Anthropocene), the value of historical references in setting restoration goals appears to diminish (Millar et al. 2007). If these historical references recede in importance, then the validity of restoration itself may be undermined.

Changes in the meaning and importance of historical knowledge have profound implications for restoration science and practice. White (1990) has argued that landscapes provide the "material grounding of human history", describing a reciprocal relationship between people and the landscape. Here we distinguish "history" from "the past": the past presumably happened, but without the interpretive capacity of history, we would know nothing about it. This particular enterprise is always contingent on the kinds of evidence available (eg material, written, oral) and on the person who interprets that evidence. We refer to "history" to indicate the interpretation of both human and ecological pasts, recognizing that such interpretations are constantly changing in response to new knowledge.

We examine potential challenges to the value of historical knowledge in restoration, and argue that discounting the importance of history in this context is both premature and unwarranted. We also acknowledge difficulties in bringing different disciplinary approaches within ecology and history together (Szabó and Hédl 2011, 2013; Pooley 2013). Specifically, by focusing on three broad categories of historical knowledge, we demonstrate that the role of history becomes more, not less, important in finding appropriate responses to rapidly changing cultural and ecological conditions. The role of history is evolving, but it will not diminish.

\section{Classical ecological restoration and historical fidelity}

Classical ecological restoration "attempts to return an ecosystem to its historic trajectory" (Society for Ecological Restoration 2004). This widely cited defini- 
tion, "the process of assisting the recovery of ecosystems that have been damaged, degraded, or destroyed", is sufficiently flexible to support a wide variety of practices. However, in this definition, restoration does not stray from "the historically rich idea of 'recovery" (Society for Ecological Restoration 2004). The motivation to seek historical references as goals for restoration projects is straightforward in the classical model: the integrity of the ecosystem in question is considered to have been greater before modern human disturbance than it is now. Thus, historical information, or reference conditions, become the primary source of ideas for what an ecosystem should be like in the future, following restoration. An attempt to return to reference conditions seems sensible, even though contemporary constraints, priorities, and land-use legacies may present formidable limitations to what can be achieved.

Varying degrees of historical fidelity to a pre-existing state can be used to determine goals for a restoration project (Clewell 2000; Higgs 2003). In cases where species composition or the recovery of at-risk species are important, the goal is to replicate as closely as possible a previous ecosystem state. In cases where past ecological conditions have been erased or obliterated (eg sites in urban areas that have been altered many times and are heavily constrained by present and adjacent land use) or are less critical to replicate, historical fidelity may be, at best, a well-educated guess that depends on references from different places and times (White and Walker 1997). Much of contemporary restoration lies between these two extremes, where historical information paired with contemporary site conditions (including an understanding of degradative processes and impacts) and other practical considerations (eg technical feasibility, financial and human resources) form the basis for restoration prescriptions or designs. Historical knowledge flexibly informs restoration designs through the application of concepts such as historical range of variability (HRV; Landres et al. 1999) or recovery of alternative successional pathways (Suding et al. 2004), without restricting designs to a particular temporal framework. The notion of historical fidelity refers, therefore, to the commitment given to an ecosystem's past in restoration design. To ignore the legacy of an ecosystem, even in cases where specific historical information is scanty, is to practice something other than restoration.

\section{- Restoration v1.0 and v2.0}

Scientific and social trends are reshaping the science and practice of restoration, posing challenges to the role of historical knowledge in setting restoration goals. Most obviously, rapid anthropogenic climate change threatens to overturn conventional assumptions about the rate and extent of ecological change as well as the relevance of historical references (Harris et al. 2006; Jackson and Hobbs 2009). Similarly, expanding global exchange of goods and services resulting from increasingly interconnected economic systems is facilitating the incidence and spread of invasive species (Norton 2009) as well as prompting debate about how best to manage the resulting hybrid and novel ecosystems (Hobbs et al. 2009, 2013). Converting land for intensive agriculture and expanding urbanization to support a growing global human population continue to place pressure on wild nature through habitat fragmentation and degradation (Nelson et al. 2010), and increase priority for urban ecosystem restoration.

From a social perspective, cultural landscapes - and restoration as a social and cultural (as well as ecological) practice - are becoming increasingly important, especially in the Global South (Nelleman and Corcoran 2010; Keenleyside et al. 2012). Models of ecological restoration developed in post-settlement North America and based on a concept of trackless wilderness are giving way to restoration goals based at least partly on sustainable human practices (Cole and Yung 2010). As ecosystems change, so too do people's beliefs about the value of those ecosystems. For example, urbanization and rapid assimilation of technologically mediated lifestyles are paving the way for more human-managed and contrived ecosystems and landscapes (Cronon 1995; Higgs 2003; Marris 2011). Finally, while the concept of ecosystem services, which is gaining traction in ecological restoration (Aronson et al. 2007), may enhance the popularity of restoration by focusing on recovering specific functions and services, there is some danger that such an approach - even one that includes non-monetized values - may reinforce an increasingly commodityoriented view of the world. A focus on ecosystem services may also downplay the importance of ecosystem elements that do not clearly support or enrich material human interests (Kosoy and Corbera 2010).

As a result of these scientific and social trends, some basic assumptions that have guided classical restoration (as defined primarily in Society for Ecological Restoration [2004]) are being challenged by the arrival of new concepts, such as novel ecosystems (Hobbs et al. 2013). Hobbs et al. (2011) proposed that restoration is increasingly untenable under conditions of rapid change, and advocated a broader and more flexible concept of "intervention ecology". At the same time, consumer-oriented cultural values may be influencing how ecosystems are valued by scientists and the general public (eg acceptance of rapid change and ecosystem service delivery) (Higgs 2003). As restoration adapts to these trends and others, it must evolve from Restoration v1.0 to a new version, Restoration v2.0 (Figure 1). Restoration v2.0 engages historical knowledge as a guide rather than a template, identifies multiple ecological trajectories, recognizes that ecological processes may take priority over structure and composition, and acknowledges that pragmatic approaches are required to address human livelihoods and cultural needs.

\section{The value of historical knowledge}

In this emerging version of restoration ecology, what role will historical knowledge play? The relevance of history 
might appear to diminish under conditions of rapid globalscale change. However, when examined analytically, there are many reasons for reasserting the role that an ecosystem's history will play in the practice of restoration.

Representing an interdisciplinary group of ecologists, historians, and philosophers, we examined and extracted nine types of historical knowledge (see below), some of which overlap and some of which function in distinctive ways (Table 1). To reduce complexity, we organized these knowledge types into three major categories - history as information and reference; as enriching cultural connections; and as revealing the future - that can be of practical value for ecological research and ecosystem management in a changing world.

\section{History as information and reference}

The first and perhaps most conventional category concerns the information that historical knowledge imparts about past ecological conditions. History provides reference information (history as reference) for understanding how ecosystems functioned in the past, and how they might operate under new conditions (eg elevated temperature, more human activity). Reference information in this sense does not bind the restorationist to a particular course of action. For example, the disturbance profile (eg mean fire return interval) of fire-dependent forested ecosystems provides vital information in setting restoration goals (Swetnam et al. 1999; Falk et al. 2006). In restoration projects, such information is derived from a wide variety of sources, including historical documents, land-use records, maps, oral histories, archaeology, and paleoecology (Egan and Howell 2001).

Reference information serves several functions. Perhaps the most obvious, and the one most subject to misuse, is the notion of the ecosystem-as-artifact, in which restoration mimics the process of restoring buildings or works of art. On the one hand, this reveals the intertwining roles of ecological restoration and historical resource management (Glassberg 2001). Restoration of the Antietam National Battlefield to its 1862 condition, for instance, includes the "replanting of historic woodlots and orchards" (NPS 2010) to convey a realistic sense of the landscape at the time of the battle. This particular approach to ecological restoration has led to a misunderstanding of restoration as returning ecosystems to exact conditions on a particular date in the past. However, it does highlight the important role that can be played by nos-

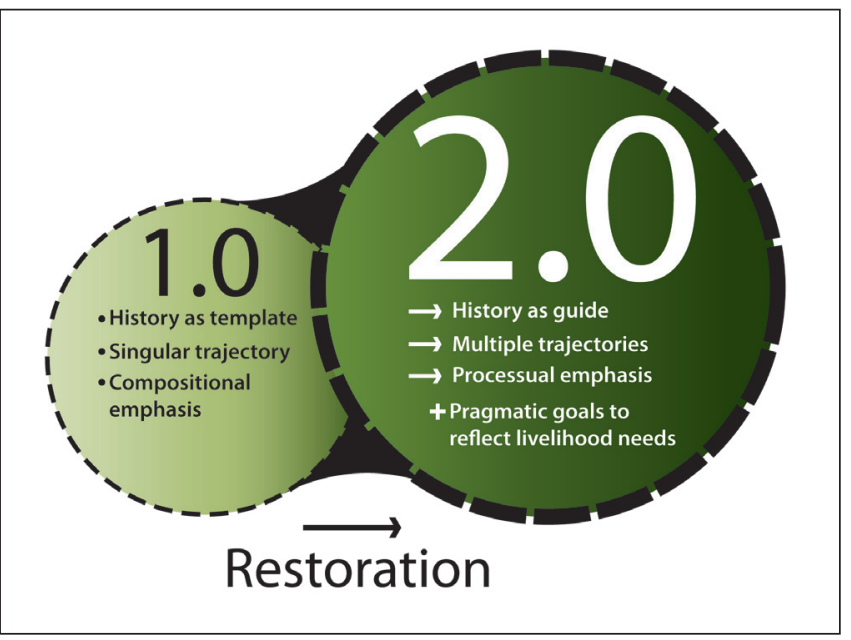

Figure 1. Restoration $v 1.0$ and v2.0. Classical ecological restoration, or Restoration $v 1.0$, with its dependence on ecological integrity and historical fidelity, has consolidated in the past three decades. With rapid ecological, environmental, and cultural change, a new version of restoration - Restoration $v 2.0$ - emphasizes flexibility in setting objectives, process over structure, and pragmatic goals that reflect the needs of people who depend on ecosystems for their livelihoods. The two versions are not entirely distinct, as Restoration v2.0 carries on the general program of recovering degraded or destroyed ecosystems.

talgia, which connects people to an imagined ecological past. Such attachment to the past sometimes motivates restoration activity and fuels retrospective examinations of past landscapes.

Another case of applying history as reference is as a baseline for change. For example, historical information is used to gauge the difference between modern, altered ecosystem states and states or trajectories prior to defined disturbance or degradation (acknowledging long records of non-industrial human engagement with ecosystems). Historical research is particularly important when reference ecosystems are lacking, or where all ecosystems have undergone a common change. For instance, the PIRLA (Paleolimnological Investigations of Recent Lake

\begin{tabular}{|c|c|c|c|}
\hline \multicolumn{2}{|c|}{ Historical knowledge } & \multirow{2}{*}{$\begin{array}{c}\text { Role in contemporary } \\
\text { restoration } \\
\text { (Restoration vl.0) }\end{array}$} & \multirow{2}{*}{$\begin{array}{l}\text { Likely role in the future } \\
\text { (Restoration v2.0) }\end{array}$} \\
\hline Categories & Types & & \\
\hline $\begin{array}{l}\text { History as information } \\
\text { and reference }\end{array}$ & $\begin{array}{l}\text { (I) History as reference } \\
\text { (2) History as range of variability } \\
\text { (3) History as legacy }\end{array}$ & $\begin{array}{l}\text { Strong } \\
\text { Strong } \\
\text { Moderate }\end{array}$ & $\begin{array}{l}\text { Steady } \\
\text { Diminishing } \\
\text { Intensifying }\end{array}$ \\
\hline $\begin{array}{l}\text { History as enriching } \\
\text { cultural connections }\end{array}$ & $\begin{array}{l}\text { (4) History as place } \\
\text { (5) History as redress } \\
\text { (6) History as governor }\end{array}$ & $\begin{array}{l}\text { Strong } \\
\text { Strong } \\
\text { Weak }\end{array}$ & $\begin{array}{l}\text { Unclear } \\
\text { Steady } \\
\text { Intensifying }\end{array}$ \\
\hline $\begin{array}{l}\text { History as revealing } \\
\text { the future }\end{array}$ & $\begin{array}{l}\text { (7) History as scenario } \\
\text { (8) History as experiment } \\
\text { (9) History as virtue }\end{array}$ & $\begin{array}{l}\text { Moderate } \\
\text { Moderate } \\
\text { Weak }\end{array}$ & $\begin{array}{l}\text { Intensifying } \\
\text { Intensifying } \\
\text { Intensifying }\end{array}$ \\
\hline
\end{tabular}

Notes: These roles were ascertained by the authors, based on experience and informed speculation, and are advanced as a starting point for further debate and refinement. 

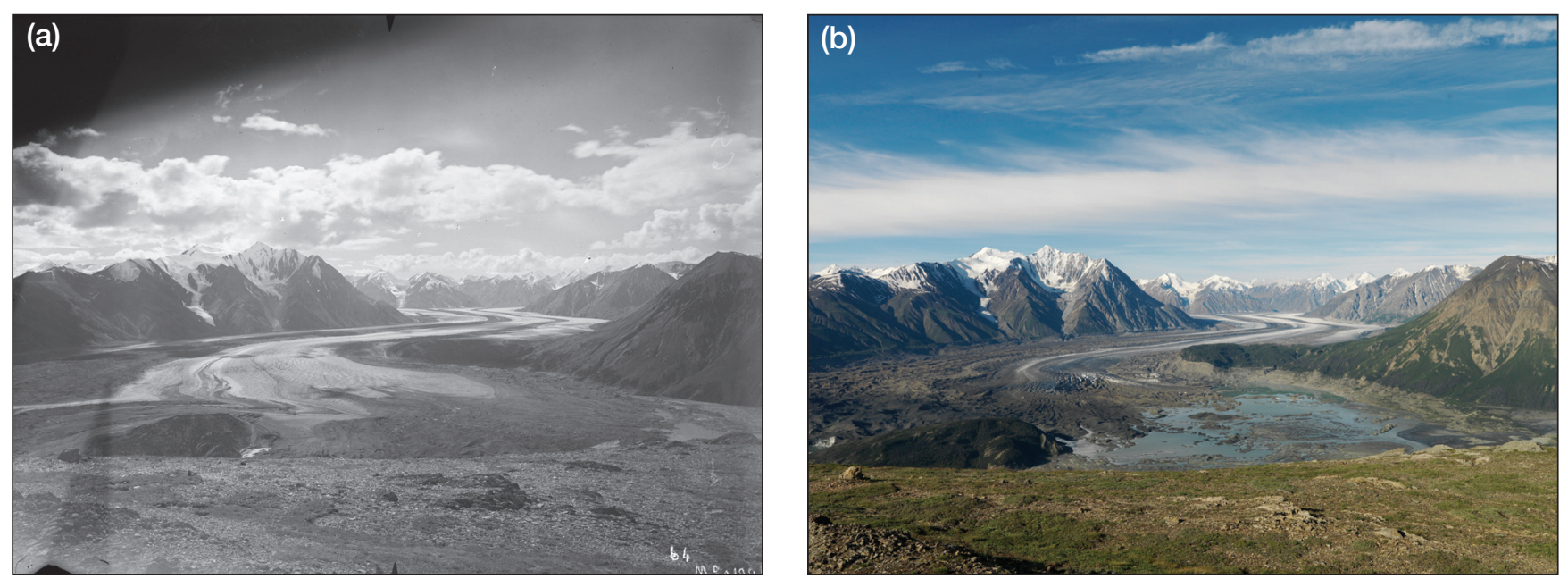

Figure 2. Paired images showing glacial change, including substantial mass wasting and retreat of the 80-km-long Kaskawulsh Glacier in Kluane National Park, Yukon Territory, Canada. The photograph in (a) was taken in 1900 by Dominion Topographic Surveyor JJ McArthur as part of his mapping "along the base of the St Elias Alps to Head of White River" near the Yukon-Alaska boundary. The photograph in (b) was taken in 2012 by the Mountain Legacy Project, a University of Victoria-based long-term research project studying widespread mountain landscape change (http://mountainlegacy.ca).

Acidification) project used lake-sediment records to determine the magnitude and timing of industrial acidification (Whitehead et al. 1990), thereby providing a baseline for restoration. Knowledge of reference conditions is also useful to determine when baselines are shifting (eg McClenachan 2009). Historical information about species ranges is also providing key baselines against which to evaluate climate and culturally driven range changes. Similarly, repeat photographs of glaciers have taught both scientists and the public important lessons about rapid environmental change in the past 150 years (Figure 2).

Recognizing the dynamism of ecosystems, an HRV in any ecosystem variable exists over a delimited interval (history as range of variability). In a restoration context, the goal is to move the ecosystem back within the bounds of various discrete parameters (Wiens et al. 2012). Canadian national park managers use HRV to restore fire regimes to coniferous-dominated forest ecosystems (Figure 3). In the absence of fire in the 20th century, widespread even-aged fire-dependent species such as lodgepole pine (Pinus contorta) have served as limits on key ecological characteristics (eg forage habitat for grizzly bears) and increased wildfire risk for adjacent human communities (Higgs and Hobbs 2010). A similar approach has been used in frequent-fire ecosystems throughout western North America, where tree-ringbased fire-scar analyses have allowed highly detailed and accurate reconstructions of spatial and temporal variation in fire regimes (Falk et al. 2011).

Legacies are the detectable signatures of the influence of the past on contemporary ecosystem composition, structure, and function (Foster et al. 2003; Rhemtulla et al. 2009). Uncovering such legacies (history as legacy) can explain the distinctive characteristics of a place and indicate constraints or challenges in shaping the ecosystem in the future. Legacies can be critical in understanding ecosys- tem processes (eg the role of initial conditions in post-disturbance succession; Temperton et al. 2004). Present historical legacies are generally products of past "combinations of climate events, disturbances, extinctions, [and] immigrations" (Jackson et al. 2009). Knowledge of such contingent events can help us understand multiple potential future ecosystem states, dependent on decisions made today as well as events beyond our control (Suding et al. 2004).

Historical records show that ecosystems are often restructured extensively during periods of rapid environmental change. For instance, Holocene pollen records for many regions of North America and Europe indicate shifting combinations of species across space and time, with these changes often occurring abruptly (Williams et al. 2011). At finer spatiotemporal scales, alternative stable or meta-stable states are observed in a wide range of terrestrial and aquatic ecosystems, arising abruptly following disturbance and environmental change (eg severe fire, altered lake chemistry), or resulting from the population dynamics of interacting species (Beisner et al. 2003). Although these changes may appear unpredictable, the legacy of the ecosystem (ie its history) nonetheless constrains the range of potential states (eg the regional pool of potential species recruiting into a community). These concepts of alternative states and resilience are increasingly being incorporated into ecosystem management and policy (Benson and Garmestani 2011).

\section{History as enriching cultural connections}

Historical knowledge strongly reinforces the sense of place (history as place). Glassberg (2001) wrote, "a sense of history and sense of place are inextricably intertwined; we attach histories to places, and the environmental value we attach to a place comes largely through the historical associations we have with it". A knowledge of the human his- 

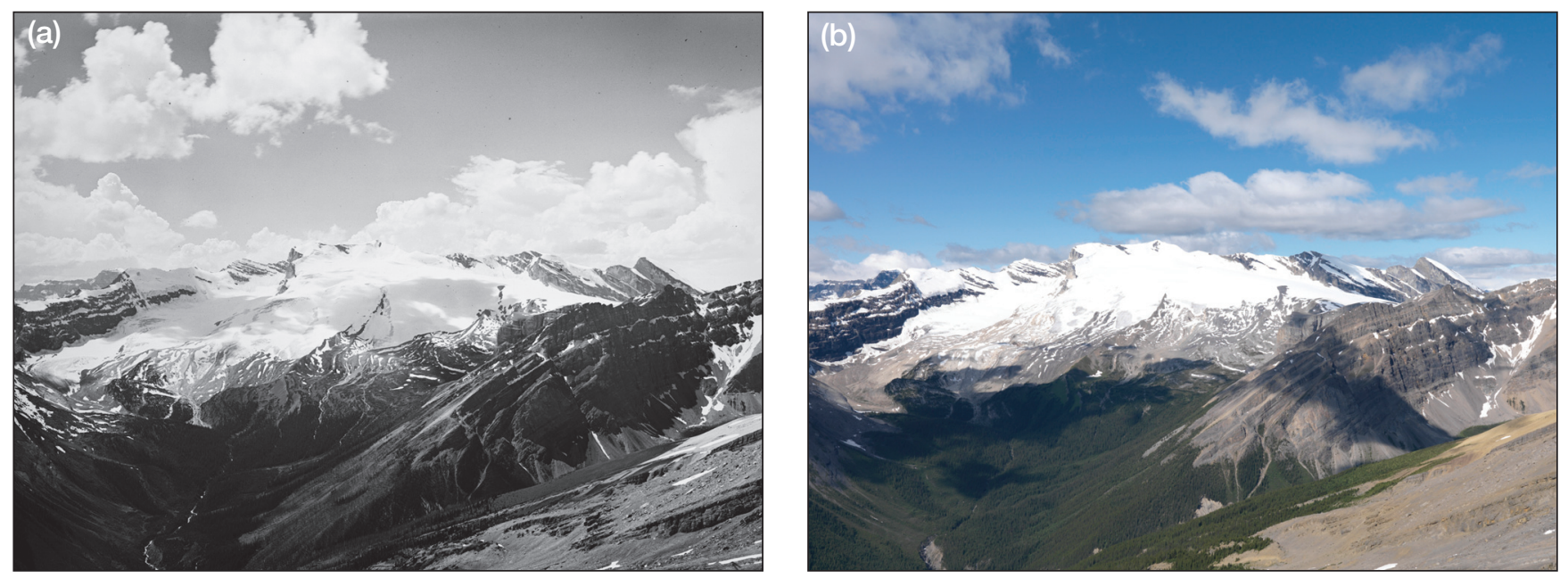

Figure 3. The power of historical evidence. The photograph in (a) was taken in 1927 by Dominion Topographic Surveyor MP Bridgland as part of his mapping of the Brazeau Forest Reserve along the Banff-Jasper National Parks boundary region. The photograph in (b) was taken in 2011 by the Mountain Legacy Project (see Figure 2). Ice and snowpack retreat are plainly evident, and vegetation patterns are clearly different as a result of historical fire activity and more recent fire suppression. Historical evidence points us in the direction of restoration alternatives: in this case, prescribed fire management and potential stand management. Historical evidence does not determine prescription but helps to set appropriate restoration goals.

tory of a landscape - not only maps of land use, but what people actually did on the land, what they thought about it, how they coped with crises - gives people (stakeholders) a critical connection to that landscape (Allen 2002).

There are also less obvious but nonetheless important ways in which historical knowledge amplifies or reinforces people's connection to ecosystems. Historical knowledge is commonly used to identify and set up conditions for redressing specific disturbances (history as redress). The historical decline of sea otter populations as a result of overhunting, for example, was followed by recovery but subsequent declines because of changes to food web dynamics (Estes et al. 1998). Here, the value of historical knowledge is in identifying the key historical disruption(s), which is the essence of classical restoration, or Restoration v1.0.

Historical human practices and beliefs are sometimes used in determining restoration goals, wherein our motivations for restoration are tied to the redress of damages to traditional ways of life and ecosystems. Restoration of Garry oak (Quercus garryana) ecosystems in southwestern British Columbia, Canada, is motivated partly by the sense of responsibility for damage done in the past as a result of land conversion, invasive species, logging, and displacement of indigenous peoples (MacDougall et al. 2004). The proximate objective of these restoration projects is recovery and conservation of native species, but a deeper goal is the regeneration of traditional ecological management practices (eg harvesting of traditional native root crops, frequent light fires, weeding; Higgs 2005).

Historical knowledge can also serve to limit our exuberant ambitions (history as governor). Just as a governor (control mechanism) works on a mechanical system to limit the maximum output or speed, history serves as a reminder to exercise caution and careful choice in how we intervene. The very act of researching the historical conditions of an ecosystem makes us remember that passage of time modifies these ecosystems, and helps us reflect on the long-term changes that an ecosystem experiences, including critical perspectives on the future of biodiversity in contemporary intervention (Naeem et al. 2012).

\section{History as revealing the future}

An unexpected outcome of identifying different kinds of historical knowledge is that some can be used to reveal potential future conditions. Historical studies can inform and enrich global-change scenario planning (history as scenario), for instance, both by providing past scenarios (a narrative that describes a sequence of events, not a fixed point in either the past or the future), and by offering an array of actual (and therefore plausible) events and ecosystem states that differ from the present (Gray 2011). By narrating a number of past scenarios for a particular site, historical information can serve as a parable or an analogy for future planning. In this respect, historical studies serve at least two other functions (Cronon 1993). First, they illuminate patterns in ecology, revealing such things as low-frequency, high-magnitude disturbances and fluctuations (eg fires, floods, megadroughts), climatic and ecological novelty in the absence of human activity, and climatic and ecological regime-shifts (Jackson 2006; Williams and Jackson 2007). Second, this long-term perspective also defines rarity: one dimension of an ecosystem's value depends on how long it has been allowed to function without substantial (systemaltering) human interventions. Thus, old-growth forests are more rare than secondary and tertiary forests. Rapidly changing conditions and human activity often 


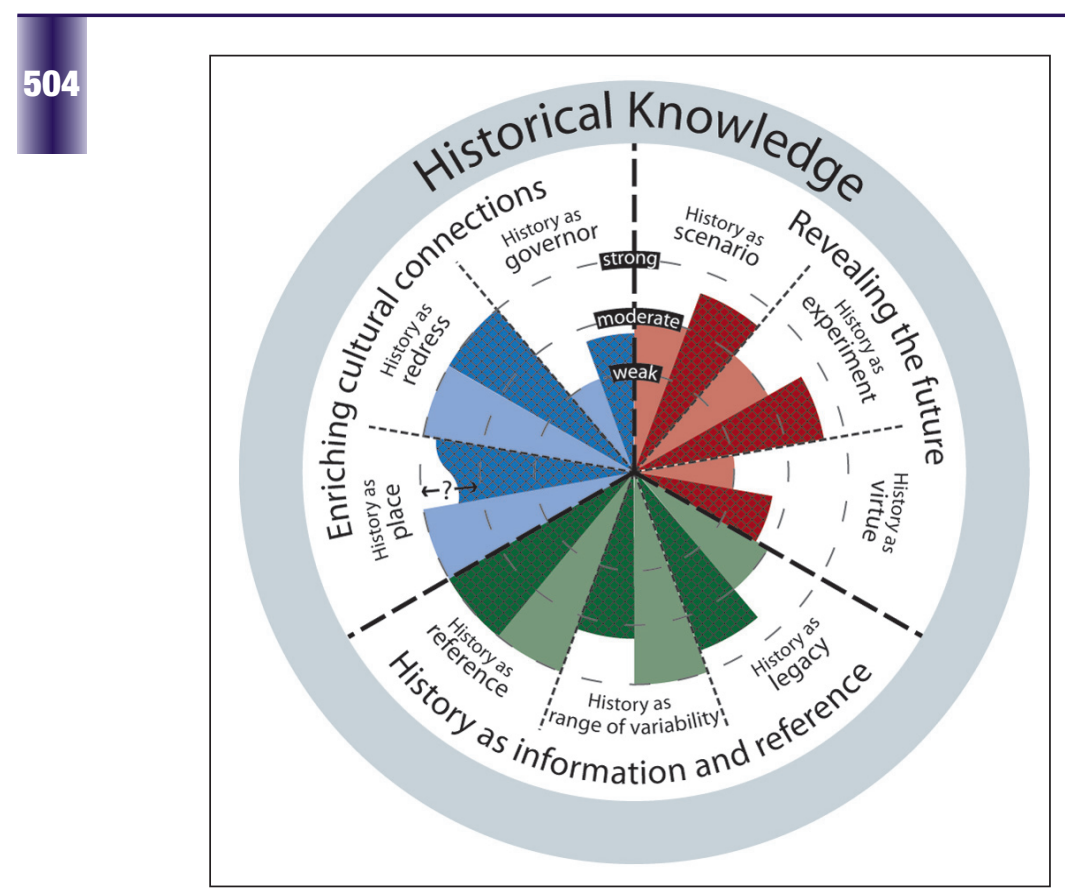

Figure 4. Categories and types of historical knowledge in the service of restoration ecology. The nine types of historical knowledge are arranged in three broader categories that describe major roles: providing information and reference, enriching cultural connections, and revealing the future. Within each of the types of knowledge, lighter and darker shading indicates present role (Restoration v1.0) and potential future role (Restoration $v 2.0$ ), respectively.

threaten rarity (Higgs 2003).

Historical knowledge also reveals a wealth of unreplicated but nonetheless valuable natural experiments (history as experiment) that suggest new research to be undertaken (Gross 2010). What are the consequences of human-mediated invasions by domesticated pigs and chickens, as well as commensal rats, on a remote oceanic island? What actually happens to an ecosystem when climate undergoes a transition or its variability increases? Do invading species dislodge native competitors or drive native prey to extinction? What is the outcome when extremely abundant, even dominant species (eg American chestnut, American bison) are largely eliminated from an ecosystem? History provides a seemingly unlimited number of unplanned experiments from which we can draw lessons for management and restoration in the future (Diamond and Robinson 2010).

Finally, there are moral dimensions to the value of historical knowledge for appropriate restoration (history as virtue). Historicity, the quality of being historical, may itself become a virtue alongside humility, self-restraint, and care for non-humans that Throop (2012) and others argued are important for ecological restoration; respect for historical fidelity highlights the limits of our ecological knowledge. In this respect, historicity constitutes a "novel virtue", one that is critical in navigating a changed world. Historicity may be restoration's virtue of the future (Higgs 2012).

\section{Discussion and conclusions}

Restorationists grappling with the impacts of rapid global change on their practices must become more sensitive to the role that history plays in restoration decisions. Two of the categories of historical knowledge (information and reference; revealing the future) are familiar to restoration ecologists; they can enhance technical knowledge derived from historical research. The other category (enriching cultural connections) is less familiar, but assists the broader practice of restoration by drawing attention to the social and cultural value of restoration (Keenleyside et al. 2012). In this respect, it provides indirect support by building a broader constituency for the science of restoration ecology.

These three categories, and the nine types of historical knowledge they encompass, should be the subject of ongoing debate and refinement (Table 1). The particular formulation presented here (Figure 4) is based on the collective interdisciplinary experience and scholarly judgment of the coauthors. It is, therefore, just an initial step. What allows us to argue that historical knowledge will be more valuable in the future than in the past is the role of contingency: ecosystems and the landscapes they comprise are shaped by myriad events and shifting interactions (see "History as information and reference"). Even if historical precedents are not exact matches with present conditions, they offer models of contingent events that can inform future restoration and management. Contingent events also encompass a range of direct and indirect human activities that shaped historical ecosystems. These can and should help guide contemporary decision-making, regardless of whether they are determined to be negative (eg directional climate change) or positive (eg local, sustainable ecosystem management). Thus, we believe that if the types of historical information that have so far been critical for restoration ecology - precise reference information and models of range of variability - become less important, other types of historical information will increase in importance.

Additional categorization is possible and may be helpful in revealing subtle distinctions, overlaps, and important nuances (we began with twenty-one types of knowledge). The three main categories discussed above help to harness the nine subcategories, demonstrating a range of historical knowledge. These categories and types are subject to the same uncertainties as any taxonomic classification, and future assessments of their value will be driven by the contingencies defined earlier and others as yet unknown. We concur with Safford et al. (2012) that "...the principal issue is not the fundamental value of historical ecology, but rather the ways in which historical information is used".

In Table 1, the nine types of historical knowledge are interpreted in terms of their relative importance to classical ecological restoration ( 1.0$)$ and to restoration responding to conditions of rapid environmental and cul- 
tural change (v2.0). Of the nine types of knowledge, seven are likely to remain important to restoration ecologists or to become more useful in the future. For example, the challenge of redressing past damage to livelihoods, especially those of indigenous peoples, will become more prominent with political and social claims of sovereignty (history as redress). Developing scenarios that assist ecologists in recommending strategies for intervention will be based on clues derived from historical information (history as legacy; history as scenario).

One type of knowledge is likely to recede in importance. In the face of rapid directional change with major uncertainties, especially where the crossing of ecological thresholds may propel ecosystems into alternative states (Suding et al. 2004), the HRV approach may become less helpful over time (Wiens et al. 2012). The magnitude of environmental change may outrun the value of HRV used conventionally in restoration ecology. It is not clear whether history as knowledge of place will diminish as well. People become strongly attached to place. For example, ecologists and a broader public assign very high value to historical and present configurations of the critically imperiled Garry oak ecosystems in British Columbia, Canada (MacDougall et al. 2004). However, it is not clear whether the transformation or loss of these familiar ecosystems in the wake of climate-driven changes will reduce or enhance commitment to them.

All of these categories and types will evolve in meaning and practice. For instance, the strict use of reference information for determining the restoration of specific historical conditions (history as artifact) may increase as ecologists and land managers struggle to maintain culturally and ecologically important ecosystems. These ecosystems may resemble museums more than they resemble restoration projects, and may require large investments to maintain species composition and structure in the face of strong pressures for change (Hobbs et al. in press). More generally, the use of history for reference information may shift from the use of reference ecosystems, which may be increasingly hard to find, to specific compositional and functional reference information that provides guidance to restoration science and practice.

The types of historical knowledge that serve as a governor (history as governor) may end up being of greatest importance in the future. Restoration ecology and ecological restoration more broadly have been effective because of their grounding in a commitment to ecological integrity and historical fidelity (Higgs 2003; Keenleyside et al. 2012). A continuing emphasis on historical knowledge has the benefit of curbing overly ambitious and potentially destructive management and restoration efforts that emphasize human interests at the expense of ecosystems. Too much attention to ecosystem services and to engineered/“designer" ecosystems will shift focus away from managing for the continuity of ecological processes and patterns over time. Conducting historical research in support of restoration science is painstaking work. In this respect, in an increasingly harried world of conservation conundrums and restoration challenges, the very act of historical research encourages the careful weighing of options. Regardless of uncertainties or disagreements about our characterizations of specific categories and types of historical information, historical methodologies and knowledge will hopefully remain an important part of restoration ecology.

\section{Acknowledgements}

We acknowledge various sources of financial and institutional support, especially the Restoration Institute (University of Victoria), the Australian Research Council, the Pacific Institute for Climate Solutions, the Society for Ecological Restoration, and the Horning Endowment at Oregon State University. We also thank C Orr for graphics assistance with Figures 1 and 4.

\section{References}

Allen CD. 2002. Lots of lightning and plenty of people: an ecological history of fire in the upland Southwest. In: Vale TR (Ed). Fire, native peoples, and the natural landscape. Washington, DC: Island Press.

Aronson JA, Milton SA, and Blignaut JN. 2007. Restoration of natural capital: science, business, and practice. Washington, DC: Island Press.

Beisner BE, Haydon DT, and Cuddington K. 2003. Alternative stable states in ecology. Front Ecol Environ 1: 376-82.

Benson MH and Garmestani AS. 2011. Can we manage for resilience? The integration of resilience thinking into natural resource management in the United States. Environ Manage 48: 392-99.

Choi YD. 2007. Restoration ecology to the future: a call for new paradigm. Restor Ecol 15: 351-53.

Clewell AF. 2000. Restoring for natural authenticity. Ecol Rest 18: 216-17.

Cole DN and Yung L (Eds). 2010. Beyond naturalness: rethinking park and wilderness stewardship in an era of rapid change. Washington, DC: Island Press.

Cronon W. 1993. The uses of environmental history. Environ Hist Rev 17: 1-22.

Cronon W. 1995. The trouble with wilderness; or getting back to the wrong nature. In: Cronon W (Ed). Uncommon ground: toward reinventing nature. New York, NY: WW Norton \& Co.

Diamond J and Robinson JA (Eds). 2010. Natural experiments of history. Cambridge, MA: Harvard University Press.

Egan D and Howell E. 2001. The historical ecology handbook: a restorationist's guide to reference ecosystems. Washington, DC: Island Press.

Estes JA, Tinker MT, Williams TM, and Doak DF. 1998. Killer whale predation on sea otters linking oceanic and nearshore ecosystems. Science 282: 473-76.

Falk DA, Heyerdahl EK, Brown PM, et al. 2011. Multiscale controls of historical fire regimes: new insights from fire-scar networks. Front Ecol Environ 9: 446-54.

Falk DA, Palmer MA, and Zedler J (Eds). 2006. Foundations of restoration ecology. Washington, DC: Island Press.

Foster D, Swanson F, Aber J, et al. 2003. The importance of landuse legacies to ecology and conservation. BioScience 53: 77-88.

Glassberg D. 2001. Sense of history: the place of the past in American life. Amherst, MA: University of Massachusetts Press.

Gray ST. 2011. From uncertainty to action: climate change projections and the management of large natural areas. BioScience 61 : 504-05. 
Gross M. 2010. Ignorance and surprise: science, society and ecological design. Cambridge, MA: MIT Press.

Hall M (Ed). 2010. Restoration and history: the search for a usable environmental past. New York, NY: Routledge.

Harris JA, Hobbs RJ, Higgs ES, and Aronson JA. 2006. Ecological restoration and climate change. Restor Ecol 14: 170-76.

Higgs ES and Hobbs RJ. 2010. Wild design. In: Cole DN and Yung L (Eds). Beyond naturalness: rethinking park and wilderness stewardship in an era of rapid change. Washington, DC: Island Press.

Higgs ES. 2003. Nature by design: people, natural process and ecological restoration. Cambridge, MA: MIT Press.

Higgs ES. 2005. The two culture problem: ecological restoration and the integration of knowledge. Restor Ecol 13: 1-6.

Higgs ES. 2012. History, novelty and virtue in ecological restoration. In: Thompson A and Bendik-Keymer J (Eds). Ethical adaptation to climate change: human virtues of the future. Cambridge, MA: MIT Press.

Hobbs RJ, Hallett LM, Ehrlich PR, and Mooney HA. 2011. Intervention ecology: applying ecological science in the twenty-first century. BioScience 61: 442-50.

Hobbs RJ, Higgs ES, Hall CM, et al. Managing the whole landscape: historical, hybrid, and novel ecosystems. Front Ecol Environ. In press.

Hobbs RJ, Higgs ES, and Hall CM. 2013. Novel ecosystems: intervening in the new ecological world order. Oxford, UK: WileyBlackwell.

Hobbs RJ, Higgs ES, and Harris JA. 2009. Novel ecosystems: implications for conservation and restoration. Trends Ecol Evol 24: $599-605$.

Jackson ST. 2006. Vegetation, environment, and time: the origination and termination of ecosystems. J Veg Sci 17: 549-57.

Jackson ST, Betancourt JL, Booth RK, and Gray ST. 2009. Ecology and the ratchet of events: climate variability, niche dimensions, and species distributions. P Natl Acad Sci USA 106: 19685-92.

Jackson ST and Hobbs RJ. 2009. Ecological restoration in the light of ecological history. Science 325: 567-68.

Keenleyside KA, Dudley N, Cairns SD, et al. 2012. Ecological restoration for protected areas: principles, guidelines and best practices. Gland, Switzerland: IUCN.

Kosoy N and Corbera E. 2010. Payments for ecosystem services as commodity fetishism. Ecol Econ 69: 1228-36.

Landres P, Morgan P, and Swanson F. 1999. Overview of the use of natural variability concepts in managing ecological systems. Ecol Appl 9: 1179-88.

MacDougall AS, Beckwith BR, and Maslovat CY. 2004. Defining conservation strategies with historical perspectives: a case study from a degraded oak grassland ecosystem. Conserv Biol 18: 455-65.

Marris E. 2011. Rambunctious garden: Saving nature in a post-wild world. New York, NY: Bloomsbury.

McClenachan L. 2009. Documenting loss of large trophy fish from the Florida Keys with historical photographs. Conserv Biol 23: 636-43.

Millar C, Stephenson NL, and Stephens SL. 2007. Climate change and forests of the future: managing in the face of uncertainty. Ecol Appl 17: 2145-51.

Naeem S, Duffy ED, and Zavaleta E. 2012. The functions of biological diversity in an age of extinction. Science 336: 1401-06.

Nelleman C and Corcoran E (Eds). 2010. Dead planet, living planet - biodiversity and ecosystem restoration for sustainable development. A rapid response assessment. Arendal, Norway: United Nations Environment Programme. www.unep.org/pdf/ RRAecosystems_screen.pdf. Viewed 10 Apr 2014.

Nelson E, Sander $\bar{H}$, Hawthorne P, et al. 2010. Projecting global land-use change and its effect on ecosystem service provision and biodiversity with simple models. PLoS Biol 5: e14327.

NPS (US National Park Service). 2010. Antietam National
Battlefield, Maryland. www.nps.gov/anti/index.htm. Viewed 1 Nov 2013.

Norton DA. 2009. Species invasions and the limits to restoration: learning from the New Zealand experience. Science 325: 569-70.

Pooley S. 2013. Historians are from Venus, ecologists are from Mars. Conserv Biol 27: 1481-83.

Rhemtulla JM, Mladenoff DJ, and Clayton MK. 2009. Legacies of historical land use on regional forest composition and structure in Wisconsin, USA (mid-1800s to 1930s to 2000s). Ecol Appl 19: 1061-78.

Safford HD, Wiens JA, and Hayward GD. 2012. The growing importance of the past in managing ecosystems of the future. In: Wiens JA, Hayward GD, Safford HD, and Giffen CM (Eds). Historical ecological variation in conservation and natural resource management. Oxford, UK: Wiley-Blackwell.

Society for Ecological Restoration (International Science \& Policy Working Group). 2004. The SER International Primer on Ecological Restoration. Washington, DC: Society for Ecological Restoration.

Suding KN, Gross KL, and Houseman GR. 2004. Alternative states and positive feedbacks in restoration ecology. Trends Ecol Evol 19: 46-53.

Swetnam T, Allen C, and Betancourt J. 1999. Applied historical ecology: using the past to manage for the future. Ecol Appl 9: 1189-206.

Szabó P and Hédl R. 2011. Advancing the integration of history and ecology for conservation. Conserv Biol 25: 680-87.

Szabó P and Hédl R. 2013. Grappling with interdisciplinary research: response to Pooley. Conserv Biol 27: 1484-86.

Temperton VM, Hobbs RJ, Nuttle T, and Halle S (Eds). 2004. Assembly rules and restoration ecology: bridging the gap between theory and practice. Washington, DC: Island Press.

Throop W. 2012. Environmental virtues and the aims of restoration. In: Thompson A and Bendik-Keymer J (Eds). Ethical adaptation to climate change: human virtues of the future. Cambridge, MA: MIT Press.

White R. 1990. Environmental history, ecology, and meaning. J Am Hist 76: 1111-16.

White PS and Walker JL. 1997. Approximating nature's variation: selecting and using reference information in restoration ecology. Restor Ecol 5: 338-49.

Whitehead DR, Charles DF, and Goldstein RA. 1990. The PIRLA project (Paleoecological Investigation of Recent Lake Acidification): an introduction to the synthesis of the project. J Limnol 3: 187-94.

Wiens JA, Hayward GD, Safford HD, and Giffen C (Eds). 2012. Historical environmental variation in conservation and natural resource management. Oxford, UK: Wiley-Blackwell.

Williams JW and Jackson ST. 2007. Novel climates, no-analog communities, and ecological surprises. Front Ecol Environ 5: 475-82.

Williams JW, Blois JN, and Shuman BN. 2011. Extrinsic and intrinsic forcing of abrupt ecological change: case studies from the late Quaternary. J Ecol 99: 664-77.

${ }^{4}$ Institute of Evolutionary Biology and Environmental Studies, University of Zurich, Zurich, Switzerland; ${ }^{5}$ School of Applied Sciences, Cranfield University, Cranfield, UK; ${ }^{6}$ School of Plant Biology, University of Western Australia, Perth, Australia; ${ }^{7}$ Department of Botany and Program in Ecology, University of Wyoming, Laramie, WY; ${ }^{\dagger}$ current address: Department of the Interior Southwest Climate Science Center, US Geological Survey, Tucson, AZ; ${ }^{8}$ Department of Geography and McGill School of Environment, McGill University, Montreal, Canada; ${ }^{9}$ Environmental Studies Department, Green Mountain College, Poultney, VT 